\title{
Survival of Casuarina cunninghamiana on a recovering sand-bed stream in the Wollombi Valley of coastal New South Wales
}

\author{
Fiona Erskine ${ }^{1}$, Anita Chalmers ${ }^{1}$ and Wayne Erskine ${ }^{1,2}$ \\ ${ }^{1}$ Centre for Sustainable Use of Coasts and Catchments, The University of Newcastle, Ourimbah Campus, PO Box 127, \\ Ourimbah, NSW 2258. ${ }^{2}$ Environmental Research Institute of the Supervising Scientist, GPO Box 461, Darwin NT 0801.
}

\begin{abstract}
The successful management and restoration of riparian corridors in Australia is currently hindered by our poor understanding of the links between hydrology, fluvial geomorphology and plant population dynamics. The aim of the current study was to determine the survival rates of Casuarina cunninghamiana subsp. cunninghamiana Miq. (family Casuarinaceae) on a sand-bed stream in the Wollombi Valley, a tributary of the Hunter River system, in coastal New South Wales (lat $33^{\circ} 02^{\prime} \mathrm{S}$; long $151^{\circ} 10^{\prime} \mathrm{E}$ ). A population planted on the banks of Dairy Arm in 1987, as part of river training works, was used to determine the long-term (24-year) survival rate. A bankfull flood in June 2011 provided an opportunity to examine the survival response of seedlings regenerating naturally within the channel. We found that $24 \%$ of the seedlings planted on the banks in 1987 had survived to adulthood. The bankfull flood significantly decreased (d.f. $=14 ; \mathrm{W}=-30 ; \mathrm{p}=0.0024$ ) median seedling density within the channel from 12 to 2 individuals per $100 \mathrm{~m}^{2}$. Seedling survival varied with height, with seedlings $>15 \mathrm{~cm}$ more likely to survive the bankfull flood. The percentage of seedlings partially buried by sediment was significantly higher $(\mathrm{d} . \mathrm{f} .=14 ; \mathrm{W}=13 ; \mathrm{p}=0.016)$ after flood compared to before flood. Seedling density was positively correlated with the amount of bare ground prior to the flood $(r=0.61 ; p=0.02)$, but this relationship was no longer significant after flood $(r=0.18 ; p=0.53) .37 \%$ of the seedlings surveyed showed evidence of grazing. Our results confirm that hydrogeomorphic processes associated with a bankfull flood affect the survival of Casuarina cunninghamiana seedlings. The management implications of our findings are discussed in terms of riparian revegetation techniques and the geomorphic recovery of over-widened sand-bed streams.
\end{abstract}

Key words: River Sheoak, seedling survivorship, flood disturbance, river training works, riparian vegetation, fluvial geomorphology

Cunninghamia (2013) 13: 295-304

doi: 10.7751/cunninghamia2013.007

\section{Introduction}

Casuarina cunninghamiana (River Sheoak) occurs naturally in New South Wales (NSW), the Australian Capital Territory (ACT), Queensland and the Northern Territory of Australia. Of the two subspecies known, only Casuarina cunninghamiana subsp. cunninghamiana occurs in NSW and the ACT (Wilson
\& Johnson 1990). The natural habitats of this tree species are riparian corridors along coastal and inland river systems where it plays an important geomorphic and ecological role by establishing in channels, locally reducing flow velocities and accelerating bench formation (Erskine et al. 2009). Bench formation is important to the geomorphic recovery of sand-bed streams as one of the processes through which 
channel contraction of over-widened streams occurs (Erskine et al. 2012). Many sand-bed streams have been overwidened by historical land management practices combined with the impacts of catastrophic floods or a series of large floods (Erskine \& Chalmers 2009; Erskine et al. 2012). Selfsustaining populations of Casuarina cunninghamiana are essential for the stability and recovery of sand-bed streams especially those that have been extensively cleared. This species is ecologically important because it lowers stream temperature by shading, provides carbon (including large wood) to rivers and provides habitat for terrestrial, riparian and aquatic fauna (Roberts \& Marston 2011). Where Casuarina cunninghamiana is the dominant tree species, its cover also influences understorey composition (Chalmers et al. 2012).

Flood-tolerant plant species are adapted to survive the physical forces of flood, as well as periods of waterlogging or inundation (Kozlowski 1984; Van Steenis 1987). The degree of physical damage, inundation and waterlogging depends on the size (intensity) and duration of flood events, as well as the relative height of the landforms on which plants are growing. Survival of many riparian species also depends on their ability to access alluvial aquifers; flood frequency is important here because floodwaters replenish both groundwater and soil water (Roberts et al. 2000; Overton et al. 2006; Chalmers et al. 2009). Geomorphological processes that are mediated by flood and interact with riparian vegetation include scouring of the bed, stream bank erosion, removal of low elevation landforms (e.g. bars and benches) and the deposition of sediment to form new landforms (Bendix \& Hupp 2000; Gurnell et al. 2001; Erskine et al. 2009; Erskine et al. 2012; Gurnell et al. 2012). Non flood-mediated factors like livestock grazing also affect riparian plant survival (Robertson \& Rowling 2000; Friedman \& Lee 2002; Chalmers et al. 2006). Studies investigating the survival of Casuarina cunninghamiana are limited and the findings have sometimes been contradictory (Roberts \& Marston 2011).

Catastrophic floods are likely to affect trees of any size class growing on both low and high elevation fluvial landforms, but they are relatively rare. Smaller floods and flows (e.g. bankfull discharge) will have less impact on large established trees and on higher elevation fluvial landforms (e.g. floodplains), but do occur relatively frequently. These frequent, smaller floods are a barrier to the restoration of riparian zones if they result in repeated loss of individual plants by scouring. Understanding the survival responses of riparian trees to frequent floods will allow us to design methods to improve restoration outcomes. For example, the historical practice of planting long cuttings of exotic Willows and Poplars to stabilise stream banks was to reduce plant loss during floods but introduced exotic species with little ecological value into the landscape. A much better solution to the problem of flood scour is Bill Hicks' longstem planting technique, which enables native species to be planted deeply into stream banks (Hicks et al. 1999).
Between 1954 and 1993 extensive river training works to address channel instability by installing a range of structural works (brush, mesh or rock fences or rock training walls) and tree plantings were undertaken by the NSW Department of Land and Water Conservation (DLWC) on streams in the Hunter Valley (Erskine 1990; 1992; 2001). Casuarina cunninghamiana was planted as part of the river training works on a sand-bed stream (Dairy Arm) in the Wollombi Valley in 1987; subsequently naturally regenerating seedlings have been observed in the channel adjacent to this planting. These circumstances provided an opportunity to investigate the survival rates of Casuarina cunninghamiana on two different time-scales on a stream for which the hydrology and geomorphology are well understood. The aim of the current study was to measure: (1) the long-term survival of the cohort planted in 1987; and (2) the survival response of naturally regenerating individuals in the channel following a bankfull flood event in 2011.

\section{Study Area}

The study area covers pastoral land in the riparian corridor of Dairy Arm (lat $33^{\circ} 02^{\prime} \mathrm{S}$; long $151^{\circ} 10^{\prime} \mathrm{E}$ ), a tributary of upper Wollombi Brook in the Hunter Valley, NSW (Figure 1). Dairy Arm (total catchment area $40 \mathrm{~km}^{2}$ ) is a small capacity sand-bed stream flanked by a low floodplain. The geology of the upper Wollombi Brook drainage basin is intercalated quartzose sandstone and shale of Triassic Hawkesbury Sandstone and Terrigal Formation. Since European settlement in the early 1820 s the natural riparian vegetation has been extensively cleared (Erskine et al. 2010). The largest catastrophic flood since European settlement occurred in June 1949 and resulted in upstream channel incision and bank instability, with concurrent downstream sedimentation and channel widening (Erskine \& Melville 2008; Erskine et al. 2010). Based on channel behaviour since European settlement Erskine et al. (2010) divided the alluvial section of Dairy Arm into three zones; the upper intact zone, the incised zone and the downstream depositional zone. The reach in this study occurs entirely within the depositional zone and has experienced substantial sedimentation since 1949 because of massive upstream channel erosion by widening and incision (Erskine \& Melville 2008).

In March 1978 a catastrophic flood increased the mean bankfull channel width of Dairy Arm by $50 \%$ (Erskine et al. 2010). In 1982 the then NSW Water Resources Commission commenced river training works for erosion control by planting exotic Willows and Poplars and installing mesh fencing and stock-proof fencing (Figure 2). In 1987 the same government agency planted Casuarina cunninghamiana seedlings on the banks of the lower $3.6 \mathrm{~km}$ of Dairy Arm (Figure 2); this planting is also considered part of the river training works. These seedlings were not grown from seed, but collected from the nearby Wollombi Brook and transplanted to the banks of Dairy Arm (N. Thompson pers. comm. 2011). Though the exact location of individual plantings could not be obtained from departmental records, the plantings can be 


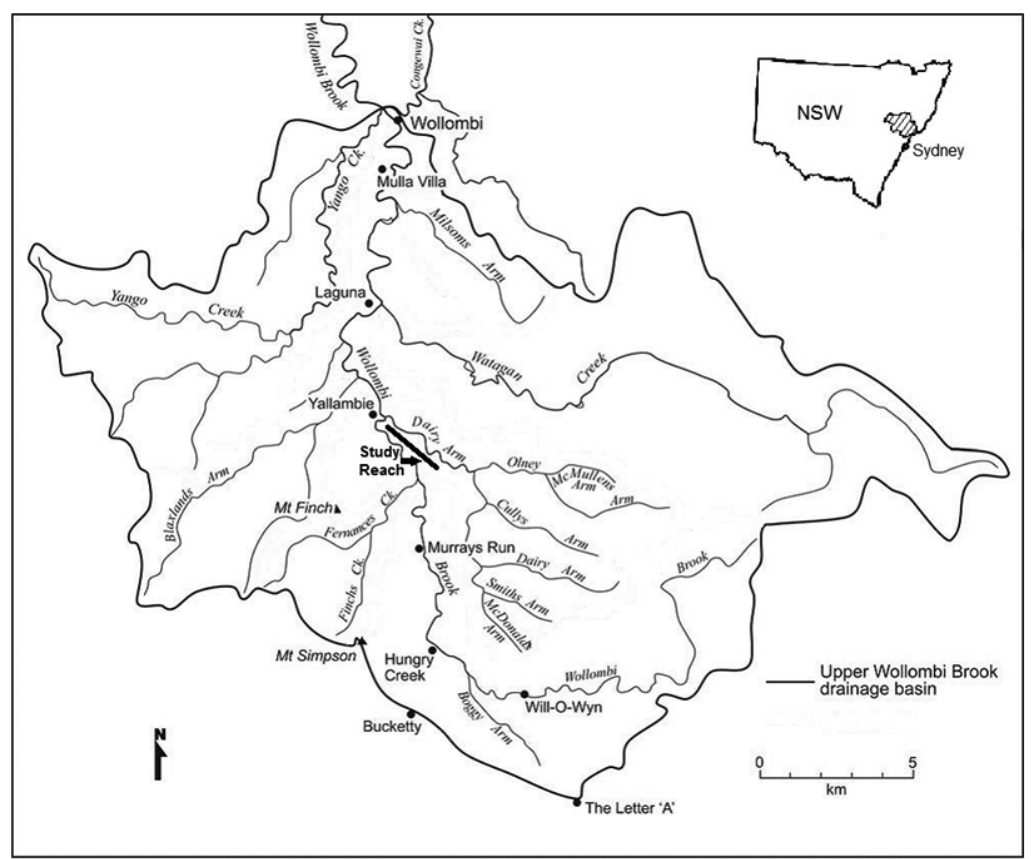

Fig. 1. Location of the study reach along Dairy Arm in the upper Wollombi Brook catchment. Inset:- general location of the Hunter Valley (hatched) within New South Wales (NSW).

easily identified in the field because: (i) they occur as a single line of evenly spaced adults of a similar size; (ii) stands are surrounded by the remnants of rectangular fences; (iii) the third author has been regularly visiting the site to conduct research since 1979; and (iv) an oral history of the site is provided by the current landowner. Note that, as a result of flood damage and the extensive sedimentation that has partially buried them, the river training fences surrounding the stands of trees no longer exclude livestock and all the sites examined in this study were now open to grazing by cattle.

Dairy Arm has a warm-temperate climate with the highest mean maximum temperature of $30^{\circ} \mathrm{C}$ in January, and the lowest mean maximum of $17.2^{\circ} \mathrm{C}$ in July (Cessnock Airport; 19 years of record; Bureau of Meteorology). The highest mean minimum temperature of $16.2^{\circ} \mathrm{C}$ occurs in February, whilst the lowest mean minimum temperature of $4^{\circ} \mathrm{C}$ occurs in July. Rainfall data were available from the Yallambie Rainfall Station (Station 61205; 51 years of record; Bureau of Meteorology) located about $200 \mathrm{~m}$ from the most downstream site investigated (Site 5). The area has a summer

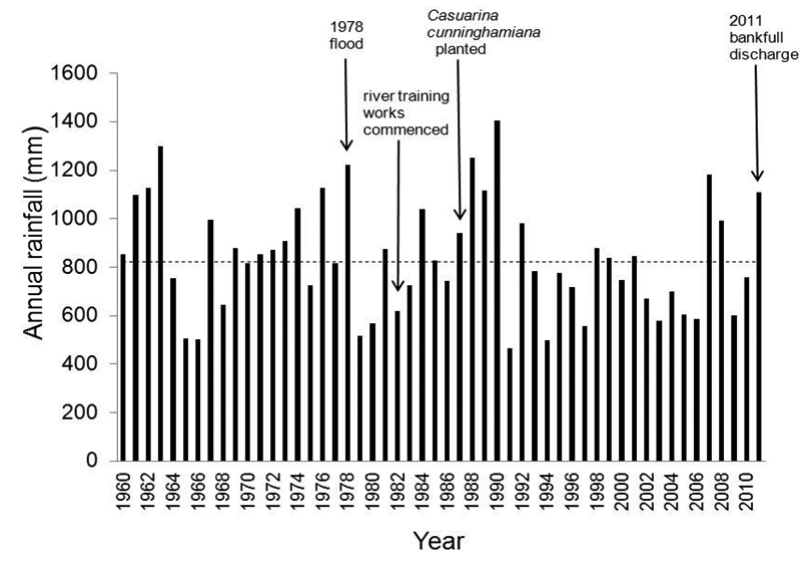

Fig. 2. Annual rainfall (black bars) and the long-term median (dashed line) at Yallambie near Dairy Arm (Station 61205; 51 years of record; Bureau of Meteorology).

Table 1. Return period (years on the annual series) of major storm events based on Yallambie (61205) record in Dairy Arm. Maximum 1-day, 2-day \& 3-day rainfall totals ( $\mathrm{mm})$ are shown in parentheses.

\section{Storm event}

March 1978

\section{1-day duration rainfall}

February 1990

$$
33(166)
$$

June 2007

89 (185)

June 2011
Return periods (years)

\section{2-day duration rainfall}

$33(221)$

15 (173)

89 (226)

4 (109)

\section{3-day duration rainfall}

89 (272)

15 (204)

33 (246)

3 (111) 
rainfall maximum and the median annual rainfall is $822 \mathrm{~mm}$. The highest mean monthly rainfall occurs in February and the lowest in July. Rainfall in 2011 was well above the longterm median (Figure 2).

There is no river gauging station on Dairy Arm but a bankfull discharge event occurred on Dairy Arm between 12 and 16 June 2011. Bankfull discharge is the maximum discharge that can be contained within the channel without the flow spilling over the banks (Simon et al. 2004). Although technically not a flood, because the flow did not overtop the banks (N. Thompson pers. comm. 2011), for the sake of brevity we will use the term flood rather than bankfull discharge. The total rainfall recorded at Yallambie during this 5-day period was $164 \mathrm{~mm}$ and the maximum daily rainfall was $84 \mathrm{~mm}$ (on 13 June). Based on this rainfall record, intensity-frequencyduration analysis shows that the June 2011 storm had a return period of 3 to 4 years, depending on duration (Table 1). This storm event was much smaller than those that contributed to the large floods of June 2007 and March 1978, both of which have a return period of 33-89 years (Table 1 ). In comparison, the February 1990 flood was associated with a storm event that has a return period of about 15 years (Table 1).

The composition of the remnant vegetation along the study reach is consistent with Wollombi Alluvial Red Gum - Apple Forest (as defined by Peake 2006), a tall open forest (12-25 m) with $10-15 \%$ cover. In this vegetation community Casuarina cunninghamiana typically occurs along river banks of high energy, where it is usually the only tree present (Peake 2006). However, in Dairy Arm, Casuarina cunninghamiana had been completely eradicated from the riparian corridor by 1979 (when we first started researching Dairy Arm) and the present population is the result of the plantings in 1987 . We have not observed any Casuarina cunninghamiana on the upstream part of Dairy Arm, nor on its upstream tributaries. However, this species does occur downstream of the study site on Wollombi Brook. The main other woody species observed on the banks and the floodplain of the study reach include Acacia parvipinnula (Silver-stemmed Wattle), Angophora floribunda (Rough-barked Apple), Eucalyptus amplifolia var. amplifolia (Cabbage Gum) and Melaleuca decora.

\section{Methods}

We chose five sites along Dairy Arm, based on existing stands of Casuarina cunninghamiana planted in 1987, counted the number of trees in each of the five stands, and walked a transect along the banks of Dairy Arm to establish whether any isolated adult trees (or saplings) existed between the fenced stands. Only two additional trees were found, and despite the absence of fencing, their size and the fact that they occurred on the bank $<20 \mathrm{~m}$ downstream of a line of Poplars and Willows was consistent with them having been planted in 1987. These two trees were included in the calculation of the long-term survival rate. We measured the maximum height of each stand and the diameter at breast height (dbh) of each tree to determine the size class distribution of the surviving population. For each tree we recorded the presence/absence of fruit to determine the proportion of the population that was potentially producing seed. There were no seedlings ( $<$ $1.5 \mathrm{~m}$ ) on the floodplain and seedlings were extremely rare on the high benches. To determine the survival response to a bankfull discharge Casuarina cunninghamiana densities were only measured within the channel.

At each site we used three $10 \mathrm{~m}$ x $10 \mathrm{~m}$ quadrats placed within the channel. Use of a $10 \mathrm{~m}$ x $10 \mathrm{~m}$ quadrat meant that the fluvial landforms sampled typically included the bed (covered with water), mid-stream and bank-attached bars and low benches (Erskine \& Livingstone 1999). We positioned the three quadrats so that the first quadrat was 20 m upstream of the canopy edge of the adult stand, the second quadrat was placed at the mid-point of the stand length and the third quadrat was positioned $20 \mathrm{~m}$ downstream of the canopy edge of the stand. We measured the bankfull width of the channel; the mid-point of the channel width became the centre point of each 10 x $10 \mathrm{~m}$ quadrat. We had to alter the method at site 4 because, instead of one stand, there were two small stands separated by a relatively small gap $(98 \mathrm{~m})$. In this case, we set the first quadrat $20 \mathrm{~m}$ from the upstream canopy edge of the stand furthest upstream while the third quadrat was set up $20 \mathrm{~m}$ from the canopy edge of the stand furthest downstream. To avoid the potential influence of the gap, we randomly selected one of the stands and set up the "second" quadrat adjacent to the mid-point of that (upstream) stand. In each quadrat we visually estimated the percentage cover of bare ground, water and ground layer vegetation, counted the number of Casuarina cunninghamiana individuals and measured their height. As the tallest individual measured in the quadrats was $1.17 \mathrm{~m}$, density in the channel will hereafter be referred to as seedling density. For each individual, we recorded evidence of being grazed or partially buried. Partial burial was recorded as present when the root collar of the seedling was at least $1 \mathrm{~cm}$ below the ground surface. In quadrats where density was high, we divided the quadrat into $1 \mathrm{~m}$ or $2 \mathrm{~m}$ strips to ensure a high accuracy of counts. The pre-flood data were collected between 7 and 10 June 2011 and the post-flood data were collected between 5 and 10 August 2011, about eight weeks after the flood. We placed the quadrats in the same location before and after flood.

We collected bed sediment at five cross sections evenly spaced through the depositional zone of Dairy Arm. On each section six equi-spaced points were bulked for each sample. The samples were oven-dried, weighed and a $100 \mathrm{~g}$ subsample, obtained by cone and quartering, was sieved through a nest of stainless sieves.

Shapiro-Wilk tests revealed that both the pre-flood $(\mathrm{W}=0.50$; $\mathrm{p}<0.0001)$ and post-flood $(\mathrm{W}=0.62 ; \mathrm{p}<0.0001)$ density data were highly skewed. Both logarithmic and square root transformations failed to improve normality and therefore we used a non-parametric Wilcoxon signed rank test (Sokal \& Rohlf 1995) to compare density in the channel, before and after flood. Seedling density measured in the middle quadrat at Site 4 was an outlier (353 seedlings in $100 \mathrm{~m}^{2}$ ), so we removed this point when conducting spearman correlations between seedling number, bare ground and vegetation cover. Paired t-tests were conducted on square root transformed 
data, to test for a difference in bare ground, vegetation cover and channel width before and after flood. As transformation did not improve the normality of the seedling burial data, we used a non-parametric Wilcoxon signed rank test for paired samples (Sokal \& Rohlf 1995). We used Predictive Analytical Software (PASW) version 18 (Norušis 2010) or JMP version 8 (SAS Institute 2008) for all analyses.

\section{Results}

\section{Long-term survival rate}

The survival rate of the Casuarina cunninghamiana seedlings planted in 1987 was $24 \%$ over the 24 year period ( 72 of 300 planted seedlings surviving). The surviving population had a mean diameter at breast height of $31.5 \mathrm{~cm}( \pm 1.87 \mathrm{~cm} \mathrm{SE})$ and a bell-shaped size distribution (Figure 3 ). The adult stands ranged from 37 to $147 \mathrm{~m}$ in length and consisted of 4-23 individuals with an average canopy height of $18 \mathrm{~m}$ $( \pm 1.3 \mathrm{~m} \mathrm{SE})$. All stands consisted of a single line of trees located just before the start of the floodplain and usually (the exception being Site 1) with a high bench having formed on the channel side of the planting since the construction of the river training works (Erskine et al., 2010). 58\% of the adult trees were producing fruit.

\section{Survival response to the June 2011 flood}

Following the flood the median density of seedlings within the channel decreased significantly from 12 seedlings per $100 \mathrm{~m}^{2}$ (inter-quartile range $=58$ ) before the flood to 2 seedlings per $100 \mathrm{~m}^{2}$ (inter-quartile range $=7$ ) after flood; this difference in density was significant (d.f. $=14 ; \mathrm{W}=-30$; $\mathrm{p}=0.0024$ ) with the Wilcoxon signed rank test. Seedling loss was the result of both flood scour and burial by sediment. Prior to the flood the majority of seedlings were less than 30 $\mathrm{cm}$ tall (Figure 4) and few seedlings were greater than $46 \mathrm{~cm}$ in height. Seedling survival after the flood varied with height class (Figure 4). Seedling survivorship tended to increase as the height of the seedlings increased, e.g. only $9 \%$ of seedlings $<5 \mathrm{~cm}$ tall survived, whilst $30 \%$ of seedlings in the 31-45 cm height class survived the bankfull flood (Figure 4). Seedling survivorship in the $>76 \mathrm{~cm}$ height class was $>100 \%$ and is most likely explained by two seedlings being missed in the pre-flood sampling.

As the "seedling" class measured here could include individuals up to $1.2 \mathrm{~m}$ tall, those few individuals in the larger size classes may be up to 1-2 years old, especially if grazed.

The Wilcoxon signed rank test showed that the percentage of seedlings partially buried by sediment was significantly higher (d.f. $=14 ; \mathrm{W}=13 ; \mathrm{p}=0.016$ ) after the flood compared to before the flood (Table 2). The variability in the seedling burial data was partly due to a distinct difference between sites. Sites 1 and 2 showed no evidence of partial burial of seedlings before or after the flood, while at the more downstream sites (4 and 5) a small proportion (about 1-5\%)

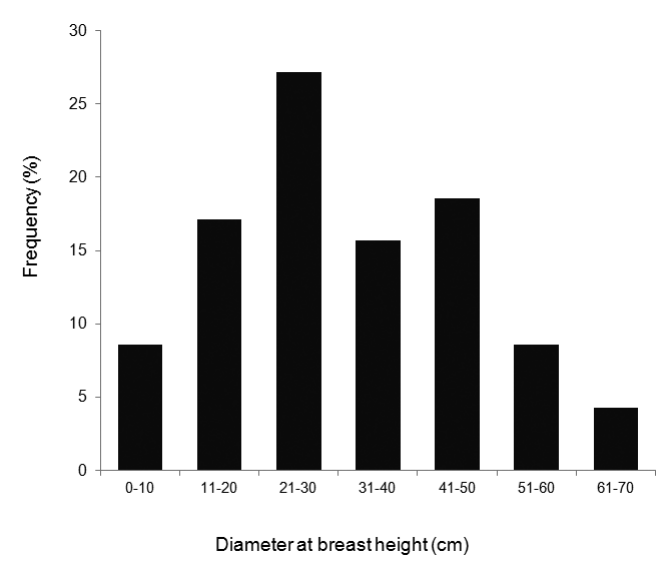

Fig. 3. Diameter size class distribution of the surviving 24 year old Casuarina cunninghamiana population in 2011, originally planted on the banks of Dairy Arm in 1987. Population mean dbh is $31.5 \mathrm{~cm}$ $( \pm 1.87 \mathrm{~cm} \mathrm{SE})(\mathrm{n}=72)$.

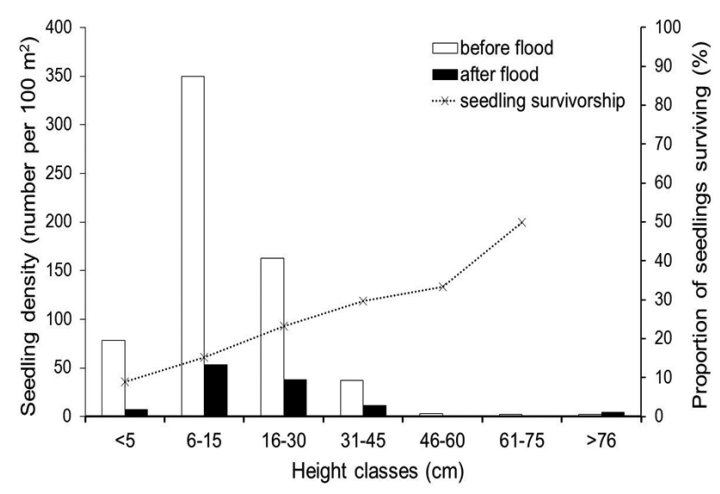

Fig. 4. Height class distribution of Casuarina cunninghamiana seedlings in $100 \mathrm{~m}^{2}$ quadrats within the channel of Dairy Arm before and after the June 2011 bankfull flood and the proportion of seedlings surviving the flood $(\mathrm{n}=15)$ (dotted line).

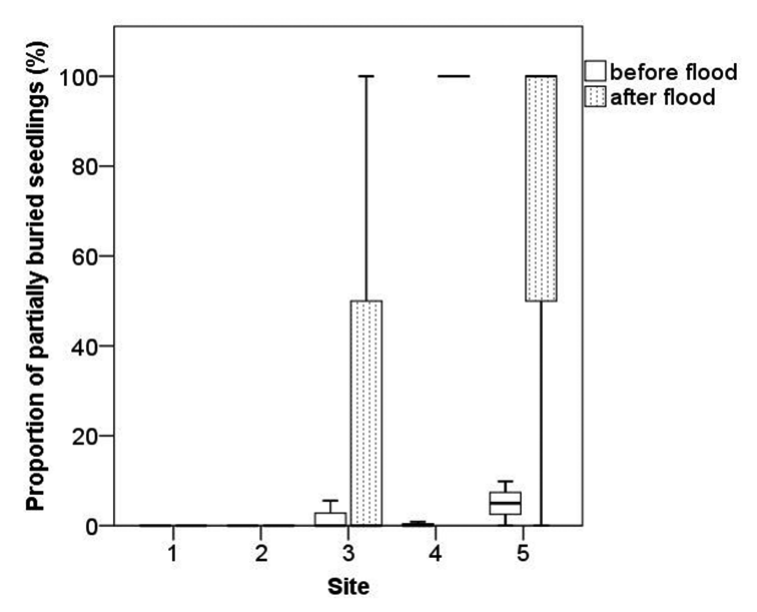

Fig. 5. Proportion of Casuarina cunninghamiana seedlings in the channel that were partially buried by sediment, before and after the June 2011 bankfull flood at each of the five study sites $(n=3)$. 


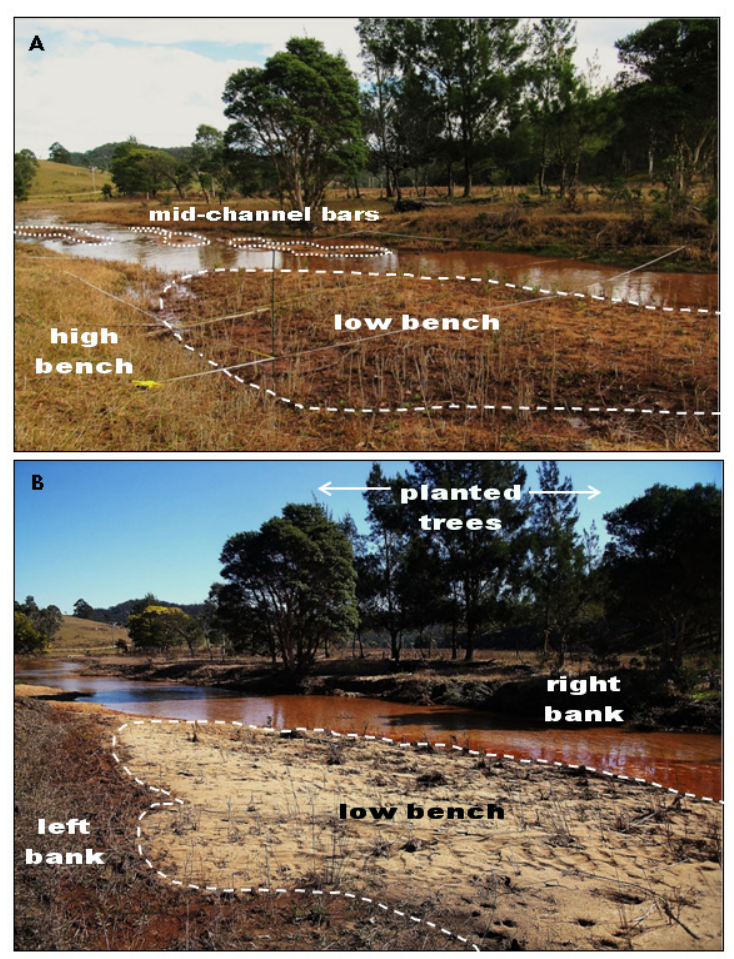

Fig. 6. Photos of the channel at Site 4 on Dairy Arm in 2011, looking downstream (A) immediately before, and (B) 8 weeks after bankfull flood. The 1987 planted trees are in the background. Photos: A. Chalmers (7 June 2011) \& F. Erskine ( 5 August 2011).

were partially buried before the flood and $100 \%$ of seedlings were partially buried after the flood (Figure 5). Spearman correlations showed that mean seedling density in the channel prior to the flood was significantly positively correlated with the mean percentage of bare ground $(\mathrm{r}=0.61 ; \mathrm{p}=0.02)$, but this relationship was no longer significant after flood $(\mathrm{r}=0.18 ; \mathrm{p}=0.53)$. There was no significant relationship between seedling density and percentage of vegetation cover, either before the flood $(\mathrm{r}=-0.2 ; \mathrm{p}=0.38)$ or after the flood $(r=0.29 ; p=0.30) .37 \%$ of the seedlings within the channel showed evidence of grazing (Table 2).

Table 2. Mean $( \pm \mathrm{SE}$ ) percentages of bare ground, vegetation cover, grazed \& partially buried Casuarina cunninghamiana seedlings and channel width at Dairy Arm $(n=15)$ before and after the June 2011 bankfull flood.

$\begin{array}{lll} & \text { Before flood } & \text { After flood } \\ \text { Bare ground (\%) } & 26 \pm 5.1 & 30 \pm 5.7 \\ \text { Vegetation cover (\%) } & 32 \pm 5.5 & 21 \pm 3.5 \\ \text { Grazed seedlings (\%) } & 37 \pm 12.9 & \text { Not determ. } \\ \text { Buried seedlings (\%) } & 1.9 \pm 0.58 & 60 \pm 16.3 \\ \text { Channel width (m) } & 8.1 \pm 0.91 & 10.2 \pm 0.86\end{array}$

\section{Channel response to the June 2011 flood}

Channel width was significantly greater $($ d.f. $=14 ; \mathrm{t}=-2.8$; $\mathrm{p}=0.014$ ) after flood compared to before flood (Table 2). Percentage of bare ground (i.e. bare sediment) was not significantly different (d.f. $=14 ; \mathrm{t}=-0.22 ; \mathrm{p}=0.83$ ) before and after flood (Table 2). Note that percentage of bare ground has probably been underestimated here, as the method did not include bare sediment covered by water, which was greater during the sampling period after flood. Vegetation cover was lower after flood compared to before flood (Table 1), but this difference was not significant (d.f. $=14 ; \mathrm{t}=2.1 ; \mathrm{p}$ $=0.055$ ). Paired photos taken at Site 4 provide an example of landforms typically found in the channel of the depositional zone of Dairy Arm and how these landforms were affected by the flood (Figure 6). Site 4 had the greatest mean density of seedlings in this study, and this site had both mid-channel bars (adjacent to Melaleuca decora in the background) and a large low bench (in the foreground) that was partially vegetated before the flood (Figure 6a). The mid-channel bars were removed by the flood and a fresh layer of sand was deposited on the low bench attached to the left bank of the stream (Figure 6b). A large proportion (89\%) of the seedlings in this particular quadrat (mainly on the low bench) were either removed by scour or buried by sand.

The median bed sediment size was consistently between 0.22 and $0.25 \mathrm{~mm}$ in diameter at all cross sections. The sand was always moulded into an asymmetrical small-scale ripple with a steeper stoss than lee slope.

\section{Discussion}

Quantification of survival rates is needed if we are to fully understand the population dynamics of riparian species and design more successful restoration programs. Erskine et al. (2009) proposed that Casuarina cunninghamiana seedlings in the bed and on low bars of sand-bed streams would be periodically removed by high flows but they were unable to provide direct evidence that this occurred. The current study confirms that while lower elevation fluvial landforms are ideal habitats for germination, up to $90 \%$ of seedlings may be lost in some locations as a result of a bankfull flood.

According to Simon et al. (2004), bankfull discharge has sufficient velocity to alter the river bed of sand-bed streams. The increase in channel width confirms that the river bed of Dairy Arm was altered by the bankfull event, but surprisingly bare ground and vegetation cover within the channel were not substantially altered. Nevertheless, paired photographs illustrate that at some locations mid-channel bars were removed and sediment was deposited on low benches within the channel.

We also found that a bankfull flood was sufficient to remove (or bury) many, but not all, of the Casuarina seedlings growing within the channel. Of those seedlings that survived the flood, about $60 \%$ were partially buried. This 
is not surprising because the median grain size of the bed material on Dairy Arm in the study area is $0.22-0.25 \mathrm{~mm}$ and is transported by nearly all discharges. How well, or for how long, seedlings can tolerate partial burial or recover from complete burial is currently unknown. Anecdotal observations in this study indicated that some seedlings just visible above the deposited sediment had not survived. Species that occur in similar environments to Casuarina cunninghamiana, such as Poplars and Willows have been found to succumb to burial (Johnson 1994; Scott et al. 1996). The study reach is within the depositional zone of Dairy Arm and has experienced substantial sedimentation since 1949 because of massive upstream channel erosion (Erskine \& Melville 2008). Erskine et al. (2010) show that medium sand has been slowly moving downstream; the upstream supply is now being reduced as it becomes exhausted and the sand remaining in storage within the channel is stabilised by vegetation (particularly by grasses). As the supply of sand to the lower reach of Dairy Arm (e.g. sites 4 and 5) reduces, we would expect that seedling survival will increase.

In the only other study to quantify survival rates of Casuarina cunninghamiana, Chalmers et al. (2009) found that 3-30\% of young adult trees (13 $\mathrm{m}$ in height) were removed from benches at Widden Brook during an overbank flood (in June 2007). Our results confirm that scouring by bankfull discharge events, which may occur every 3 to 4 years, is a barrier to re-instating self-sustaining populations of Casuarina cunninghamiana on streams that have been previously cleared of riparian vegetation. As most riparian restoration practitioners know through experience, any technique that can reduce the impacts of scouring will improve restoration outcomes which is why the long-stem planting technique is recommended by a number of restoration practitioners (Hicks et al. 1999; Peel 2010) for use in riparian zones.

Seedling loss in the current study was due to flood scour or burial; there was no evidence of impacts from inundation. Woolfrey \& Ladd (2001) found that continuous submergence of at least 2 months eliminated Casuarina cunninghamiana seedlings in the channel of the Murrumbidgee River, but wading depths observed during sampling in Dairy Arm suggested that stream height was almost back to pre-flood conditions after $7 \frac{1}{2}$ weeks - consistent with the duration of inundation being too short to affect survival.

Prior to the bankfull flood, the height class distribution of seedlings suggested that regeneration within the channel of Dairy Arm is episodic, rather than continuous, as many seedlings were about the same height. Episodic recruitment occurs when abundant seed release coincides with favourable habitat and climatic conditions (League \& Veblen 2006). Based on the even-aged stands regenerating on benches, Erskine et al. (2009) concluded that establishment of Casuarina cunninghamiana within the channel of Widden Brook is episodic. The positive relationship between seedling density and percentage bare ground within the channel found here is consistent with other studies on the regeneration of exotic pioneer riparian tree species (Bradley \& Smith
1986; Cremer et al. 1995) and Casuarina cunninghamiana (Woolfrey \& Ladd 2001). However, our results suggest that this relationship may no longer be evident if sampling occurs shortly after a flood that is sufficiently large to alter the bed. The change in the height distribution before and after the bankfull flood shows that a greater proportion of smaller seedlings $(<15 \mathrm{~cm})$ were removed or buried. Presumably larger seedlings are better able to resist high flows, by having a more developed root system that anchors them to the bed, and their greater height would reduce the risk of being completely buried. Thus, the size class distribution will not only reflect establishment events, but the episodic nature of loss due to floods.

In May 1982 exotic Willow and Poplar plantings and extensive stock-proof fencing were installed in Dairy Arm (Erskine et al. 2010), and 300 Casuarina cunninghamiana seedlings were planted five years later (month of planting unknown) by the same government agency. The bell-shaped size distribution of the surviving population is consistent with the trees being established at the same time. $24 \%$ of these remain 24 years later and just over half of them produced fruit in 2011; a survival rate within the range found by previous studies of planted riparian trees and shrubs. Webb et al. (1999) found survival rates of tree species that typically occur in riparian habitats along sand-bed streams in the Hunter Valley ranged from 33\% (Angophora floribunda) to $89 \%$ (Eucalyptus camaldulensis) (measured 14 years after being planted). Unfortunately there is no comparative data for Casuarina cunninghamiana survival because this species was not usually planted as part of river training works at that time, despite its widespread distribution in the region (Webb et al. 1999). However Hicks et al. (1999), reporting on the survival of four riparian tree species planted at two sites in the Hunter Valley, compared the performance of long-stem and standard tube-stock and included Casuarina cunninghamiana. Eleven months after planting, 69\% of the long-stem plants had survived compared to $19 \%$ of those planted as standard tube-stock. Thus the survival rate of the standard tube-stock in their study is similar to the survival rate reported here.

In contrast to the survival rate after the June 2011 flood (which isolates the impact of a discrete disturbance event), the longterm survival rate integrates the potential effects of floods, droughts, sedimentation and grazing. The 1987 seedlings used for river training works were apparently obtained from neighbouring Wollombi Brook and transplanted to the banks of Dairy Arm (N. Thompson pers. comm. 2011). The mean annual rainfall at Dairy Arm (at Yallambie) between 1959 and 1990 was about $16 \%$ higher than between 1991-2008 (Erskine et al. 2010) (Figure 2). Being planted on the banks of an over-widened channel just at the end of a relatively wet period would have increased the chances of the planted seedlings becoming established, as water stress was probably low in the early stages of establishment (Figure 2). At least some of the plants survived the moderate-sized flood that occurred when the planting was only 3 years old (i.e. February 1990). In the absence of catastrophic floods 
during this period (Erskine et al. 2010) vegetated benches built up in the channel over time, so that by the time the large overbank flood occurred in June 2007 (Erskine \& Chalmers 2009; Erskine et al. 2010) the planted trees were protected from scouring by a bench. Though originally protected by fencing, these had largely gone by 2011 and we found that $37 \%$ of the seedlings had been grazed. The benefit of stockproof fencing on seedling abundance has been previously reported by Chalmers et al. (2006). Therefore the exclusion of livestock from the banks of Dairy Arm, during the crucial period of establishment, would have also increased the probability of seedlings reaching adulthood. Ganger records show that maintenance and repairs to the stock-proof fencing on Dairy Arm was undertaken by the then DLWC on at least six occasions between 1982 and 1997. Clearly, one-off incentive funding from government agencies for the installation of stock-proof fencing along riparian zones is likely to be inadequate because considerable repair costs due to flood damage can be expected over the life of any restoration or conservation project.

\section{Conclusions and management implications}

We found that only a small proportion of the naturally recruiting seedlings growing within the channel survived a bankfull flood and that a flood of this size can significantly increase the channel width of a sand-bed stream (at least where the vegetation on bars and low benches is predominately herbaceous). Fluvial geomorphic processes associated with a bankfull flood clearly affect the survival of Casuariana cunninghamiana seedlings, with seedling loss being due to scour and burial by sand. The high proportion of seedlings that were partially buried by sediment in this study is consistent with the reach being located in the deposition zone of Dairy Arm where highly mobile medium sand is slowly moving downstream. As sand-bed streams tend to be re-worked more often, and on a larger scale than other bed sediment types (Erskine 1996; Brierley and Fryirs, 2005; Erskine et al. 2010), the conclusions of this study are unlikely to apply to Casuarina cunninghamiana growing in bedrock or gravel-bed streams or to regions with different climatic and rainfall regimes.
However under the climatic conditions of the last 24 years, seedlings planted on the banks of Dairy Arm in 1987 were able to survive through to adulthood and supply viable seed to the channel. The rate of survival was low, but consistent with other studies of riparian species (Hicks et al. 1999; Webb et al. 1999) used in river training works in the Hunter Valley. Long-stem planting may improve survival by reducing both the risk of removal and burial by flood (Hicks et al. 1999) but further quantitative, longer-term and better designed studies on this planting technique are needed. Where standard tubestock is planted, our results suggest that seedlings $>15 \mathrm{~cm}$ in height may have an improved chance of surviving a bankfull flood. The exclusion of livestock from the banks and the channel is recommended to allow both planted and naturally regenerating seedlings to establish and reach maturity. Whilst permanent exclusion is clearly preferable (to allow the restoration of the understorey as well), a compromise would be to exclude livestock for at least 4-5 years or until most of the crown of the saplings is above the reach of grazing animals. Intermittent grazing with low stocking densities could then be used to control pasture grasses and weeds, where necessary.

Sand-bed streams in the region are still recovering from the combined effects of clearing by European settlers and postEuropean catastrophic floods (Erskine 1996; 2008; Erskine and Chalmers 2009; Erskine et al. 2010). For sand-bed streams with a large supply of sediment within the channel, high losses of seedlings through burial can be expected for some time yet. However ongoing research is showing the value of re-establishing vegetation along these channels, as formerly unstable channels are becoming more resilient to relatively large floods as a result of vegetation colonisation (Erskine 2008; Erskine and Chalmers 2009; Erskine et al. 2010). 


\section{Acknowledgements}

We thank N. Thompson for sharing his knowledge about Dairy Arm and practical assistance in conducting this study. We would also like to thank G.T. and L.N. Erskine for assistance with vegetation sampling, N. Croce for statistical advice and the NSW Land and Property Management Authority for access to the river training ganger sheet records. The authors would also like to thank the journal referees for their constructive comments and Emeritus Professor P.S. Lake for many stimulating discussions.

\section{References}

Bendix J. \& Hupp C.R. (2000) Hydrological and geomorphological impacts on riparian plant communities. Hydrological Processes 14, 2977-2990.

Bradley C.E. \& Smith D.G. (1986) Plains cottonwood recruitment and survival on a prairie meandering river floodplain, Milk River, southern Alberta and northern Montana. Canadian Journal of Botany 64, 1433-1441.

Brierley G.J. \& Fryirs K.A. (2005) Geomorphology and River Management: Applications of the River Styles Framework. Blackwell Publishing, Victoria.

Chalmers A.C., Erskine W.D., Keene, A. \& Bush R. (2006) Role of stock-proof fencing in assisting regeneration of Casuarina cunninghamiana in the Hunter Valley, NSW. $9^{\text {th }}$ International River Symposium,4-7 September 2006, Brisbane.

Chalmers A.C., Erskine W.D., Keene, A. \& Bush R. (2009). Flow regimes influencing riparian vegetation on an unregulated sandbed stream in the Hunter Valley, NSW. Proceedings of the $32^{\text {nd }}$ Hydrology and Water Resources Symposium, (pp. 770-781). 30 November-3 December, Newcastle, Australia.

Chalmers A.C., Erskine W.D., Keene A.F. \& Bush R.T. (2012) Relationship between vegetation, hydrology and fluvial landforms on an un-regulated sand-bed stream in the Hunter Valley, Australia. Austral Ecology 37, 193-203.

Cremer K., Van Kraayenoord C., Parker N. \& Streatfield S. (1995) Willows spreading by seed - implications for Australian river management. Australian Journal of Soil and Water Conservation 8, 18-27.

Erskine W.D. (1990) Hydrogeomorphic effects of river training works: the case of the Allyn River, NSW. Australian Geographical Studies 28, 62-76.

Erskine W.D. (1992) Channel response to large-scale river training works: Hunter River, Australia. Regulated Rivers: Research and Management 7, 261-278.

Erskine W.D. (1996) Response and recovery of a sand-bed stream to a catastrophic flood. Zeitschrift für Geomorphologie 40(3), 359-383.

Erskine W.D. (2001) Geomorphic evaluation of past river rehabilitation works on the Williams river, New South Wales. Ecological Management and Restoration 2, 116-128.

Erskine W.D. (2008) Channel incision and sand compartmentalization in an Australian sandstone drainage basin subject to high flood variability. In: Sediment Dynamics in Changing Environments. (eds J. Schmidt, T. Cochrane, C. Phillips, S. Elliott, T. Davies \& L. Basher) pp. 283-290. International Association of Hydrological Sciences Publ. No. 325, Wallingford.
Erskine W.D. \& Chalmers A.C. (2009) Natural river recovery from catastrophic channel changes by vegetation invasion of the sand-bedded Wollombi Brook, Australia. Proceedings The 7th International Symposium on Ecohydraulics, 12-16 January 2009, Concepcion, Chile, ISBN 978-981-08-2100-5, Paper conf187a305, 10 pp, Published on CD-Rom by ISE 2009 Organising Committee.

Erskine W.D., Chalmers A., Keene A., Cheetham M. \& Bush R. (2009) Role of a rheophyte in bench development on a sandbed river in southeast Australia. Earth Surface Processes and Landforms 34, 941-953.

Erskine W.D., Chalmers A.C. \& Townley-Jones M. (2010) The importance of sediment control for recovery of incised channels. Sediment Dynamics for a Changing Future (Proceedings of the ICCE symposium held at The Warsaw University of Life Sciences - SGGW, Poland, 14-18 June 2010). IAHS Publ. 337.

Erskine W.D., Keene A.F., Bush R.T., Cheetham M. \& Chalmers A.C., (2012). Influence of riparian vegetation on channel widening and subsequent contraction on a sand-bed stream since European settlement: Widden Brook, Australia. Geomorphology 147-148, 102-114.

Erskine W.D. \& Livingstone E.A. (1999) In-channel benches: the role of floods in their formation and destruction on bedrockconfined rivers. In: Varieties of Fluvial Form. (eds A.J. Miller \& A. Gupta) pp. 445-475. Wiley, Chichester.

Erskine W.D. \& Melville M.D. (2008) Geomorphic and stratigraphic complexity: Holocene alluvial history of upper Wollombi Brook, Australia. Geografiska Annaler 90A, 1-17.

Erskine W.D. \& Peacock C.T. (2002) Late Holocene floodplain development following a cataclysmic flood. In: The Structure, Function and Management Implications of Fluvial Sedimentary Systems. (eds F. Dyer, J. Olley \& M.C. Thoms), pp. 177-184. Proceedings of a Symposium held at Alice Springs, Australia, September 2002. International Association of Hydrological Sciences Publ. No. 276.

Friedman J.M. \& Lee V.J. (2002) Extreme floods, channel change, and riparian forests along ephemeral streams. Ecological Monographs 72, 409-425.

Gurnell A.M., Bertoldi W. \& Corenblit D. (2012) Changing river channels: the roles of hydrological processes, plants and pioneer fluvial landforms in humid temperate, mixed load, gravel bed rivers. Earth-Science Reviews 111, 129-141.

Gurnell A.M., Petts G.E., Hannah D.M., Smith B.P.G., Edwards P.J., Kollmann J., Ward J.V. \& Tockner K. (2001) Riparian vegetation and island formation along the gravel-bed fiume tagliamento, Italy. Earth Surface Processes and Landforms 26, $31-62$.

Hicks B., Raine A., Crabbe G. \& Elsley M. (1999) The use of native long-stem tube-stock as an alternative to willows for controlling streambank erosion. In: Second Australian Stream Management Conference: the challenge of rehabilitating Australia's streams. Adelaide. (eds I. Rutherford \& R. Bartley) pp. 331-334. Cooperative Research Centre for Catchment Hydrology, Clayton, Victoria.

Johnson W.C. (1994) Woodland expansion in the Platte River, Nebraska: patterns and causes. Ecological Monographs 64, 45-84.

Kozlowski T.T. (1984) Responses of woody plants to flooding. In: Flooding and plant growth. (ed T.T. Kozlowski.) pp. 129-163. Academic Press, Orlando, Florida.

League K. \& Veblen T. (2006) Climate variability and episodic Pinus ponderosa establishment along the forest-grassland ecotones of Colorado. Forest Ecology and Management 228, 98-107. 
Norušis M. J. (2010) PASW statistics 18 guide to data analysis. Prentice Hall, New Jersey.

Overton I.C., Jolly I.D., Slavich P.G., Lewis M.M. \& Walker G.R. (2006) Modelling vegetation health from the interaction of saline groundwater and flooding on the Chowilla floodplain, South Australia. Australian Journal of Botany 54, 207-220.

Peake T.C. (2006) The vegetation of the Central Hunter Valley, New South Wales. A report on the findings of the Hunter remnant vegetation project. Hunter-Central rivers Catchment Management Authority, Paterson.

Peel B. (2010) Rainforest restoration manual for South-eastern Australia. CSIRO, Collingwood, Victoria.

Robertson A.I. \& Rowling R.W. (2000) Effects of livestock on riparian zone vegetation in an Australian dryland river. Regulated Rivers Research and Management 16, 527-541.

Roberts J. \& Marston F. (2011) Water regime for wetland and floodplain plants. A source book for the Murray-Darling Basin. National Water Commission, Canberra.

Roberts J., Young B. \& Marston F. (2000) Estimating the water requirements for plants of floodplain wetlands: a guide. Land and Water Resources, Research and Development Coorporation, Canberra.

SAS Institute (2008) JMP 8 Introductory Guide. SAS Institute Inc., Cary, North Carolina.

Scott M.L., Friedman J.M. \& Auble G.T. (1996) Fluvial process and the establishment of bottomland trees. Geomorphology 14, 327-339.

Simon A., Dickerson W. \& Heins A. (2004) Suspended-sediment transport rates at the 1.5-year recurrence interval for ecoregions of the United States: transport conditions at the bankfull and effective discharge? Geomorphology 58, 243-262.

Sokal R.R. \& Rohlf F.J. (1995) Biometry: The Principles and Practice of Statistics in Biological Research. W.H. Freeman and Company, New York.

Van Steenis C.G.G.J. (1987) Reophytes of the world: supplement. Allertonia 4, 267-330.

Webb A.A., Allwood, N.L., Erskine, W.D. \& Vernon, S.L., (1999). Assessment of riparian revegetation trials on in-channel benches in the Hunter Valley, NSW. Australian Geographical Studies 37, 268-283.

Wilson K.L. \& Johnson L.A.S. (1990) Casuarinaceae. In: Flora of New South Wales - Volume 1 (ed G. Harden), Royal Botanic Gardens, Sydney.

Woolfrey A.R \& Ladd P.G. (2001) Habitat preference and reproductive traits of a major riparian tree species (Casuarina cunninghamiana). Australian Journal of Botany 49, 705-715.

Manuscript accepted 9 September 2013 